\title{
Republished:
}

\section{An elegy on the memory of Professor Mansour Ali Haseeb (Arabic poem) Mustafa Abdalla M Salih}

Source: Al hakeem 1974, Vol 9 (No 2): 62.

How to cite: Republished: Salih MAM. An elegy on the memory of Professor Mansour Ali Haseeb (Arabic poem).

Sudan J Paediatr 2013;13(2):129-131.
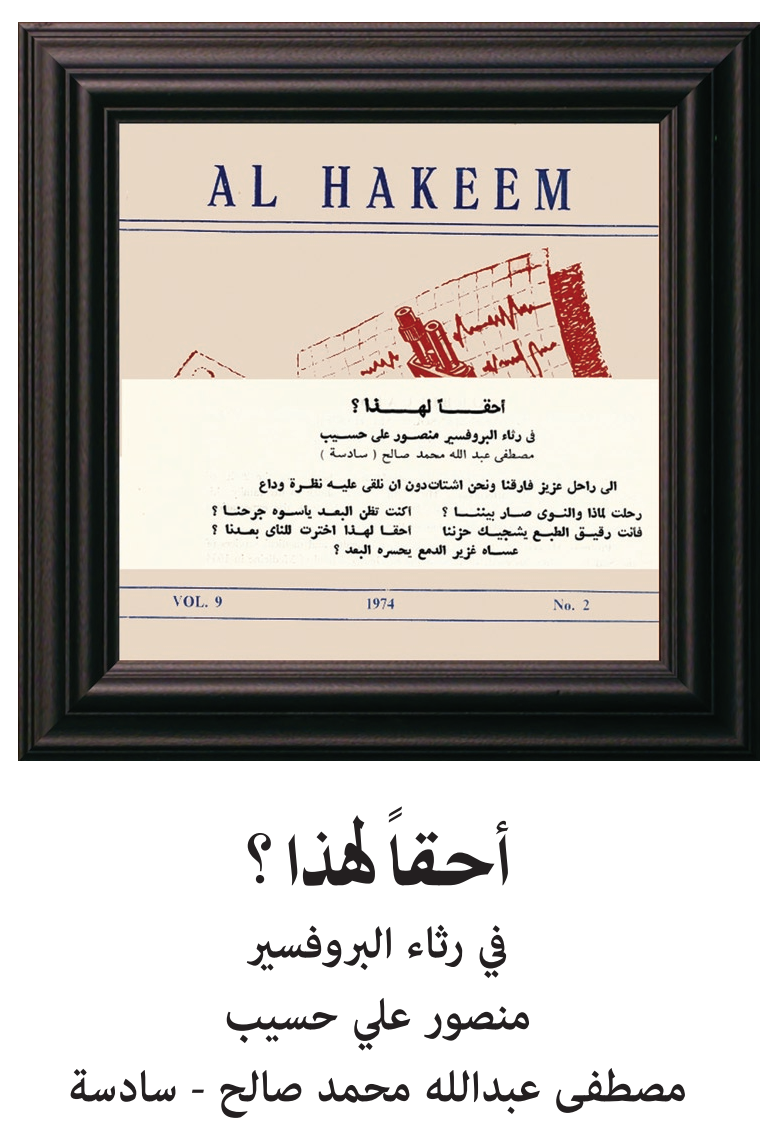

إلى راحل عزيز فارقنا ونحن أشتات دون أن نلقي عليه نظرة وداع

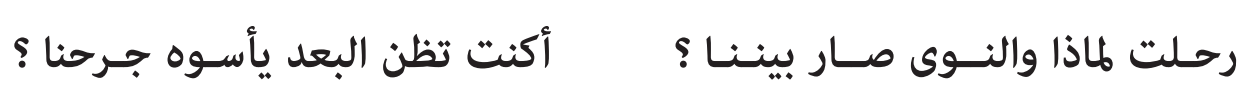

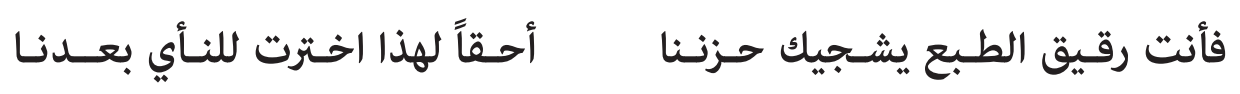

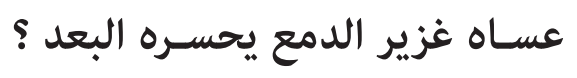




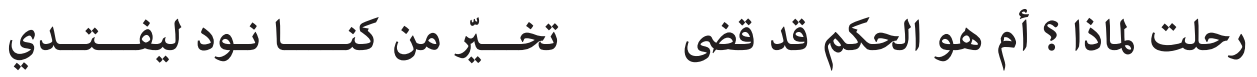

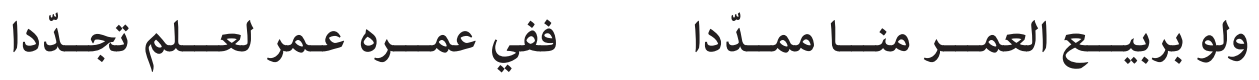

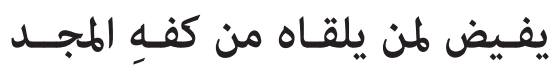

وأرثيك كيف وقد تسـاقط من يدي لفاجـعتي حسرفي وأضـى معـاندي فواحسرة في الدرب يا منصور في الغد إذا بتنا عطاشى نشـتهي كفك الندى

$$
\text { ونبـكي غمــاماً ســحّ منه لنـا الود }
$$

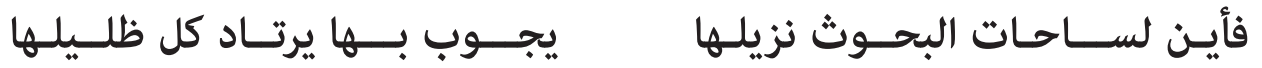


وتبــقى عطاءً سـرمد الدهــر يمتد

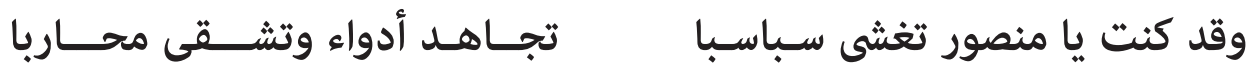
وتجـحـد نفســاً لا تروم مكاســبـاً سـوى البشر يغشى حساضرا ومضاربا بعـافـية كانت صـدى منـك يرتد

ومال " المدرّج " يصبح اليوم باكيا أيبكي عظيماً كان يلقــاه جـاثيا ؟

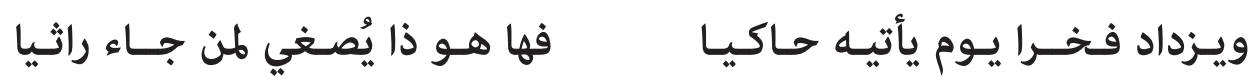

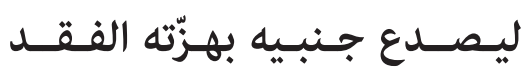

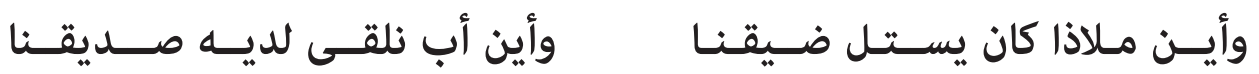

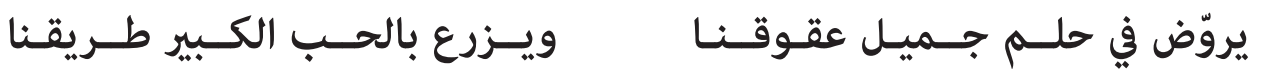

$$
\begin{aligned}
& \text { ويحـنو علينـا إذا ما الغـير يشـتد }
\end{aligned}
$$




$$
\begin{aligned}
& \text { فعفـوا فقـد عـق اللســان مهـابـة أيقـدر يحـصى حســرة غــلابــة ؟ }
\end{aligned}
$$

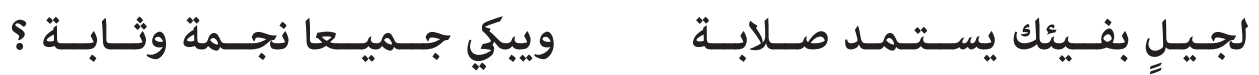

$$
\begin{aligned}
& \text { محال ! فأنت الهجد قمة ضمه لحد }
\end{aligned}
$$

